Revista Eletrônica do Mestrado em Educação Ambiental

Programa de Pós-Graduação em Educação Ambiental

\title{
Performance de un movimiento: las marchas por la legalización del aborto en
}

\section{Argentina}

\author{
Paola Bonavitta ${ }^{1}$ \\ CONICET- CIFFyH- FemGeS \\ ORCID https://orcid.org/0000-0003-4758-4202
}

\begin{abstract}
Resumen: En este artículo se propone indagar en la construcción performática del movimiento feminista a favor de la legalización del aborto en Argentina. Se analizará el lenguaje corporal y performático de quienes protagonizan las marchas a favor de la interrupción legal del embarazo desde el período febrero de 2018 hasta julio de 2019. Este recorte temporal se debe a que fue el pico más activo de participación en las marchas tras la presentación del proyecto de Ley al Congreso de la Nación. La intención es comprender lo performático de estas movilizaciones y los significados que allí se crean y recrean desde los aportes del análisis del discurso y desde la comunicación popular, así como también del feminismo latinoamericano y decolonial.
\end{abstract}

Palabras claves: Aborto legal - Performance - Movimientos sociales - Feminismos latinoamericanos

\section{Performance de um movimento: as marchas pela legalização do aborto na Argentina}

Resumo: Neste artigo, propõe-se investigar a construção da atuação do movimento feminista em favor da legalização do aborto na Argentina. Será analisada a linguagem corporal e de desempenho daqueles que protagonizam as marchas em favor da interrupção legal da gravidez de fevereiro de 2018 a julho de 2019. Esse corte temporário se deve ao fato de ter sido o pico de participação mais ativo nas marchas após o apresentação do projeto ao Congresso Nacional. A intenção é entender o desempenho dessas mobilizações e os significados criados e recriados a partir das contribuições da análise do discurso e da comunicação popular, bem como do feminismo latino-americano e descolonial.

Palavras-chaves: Aborto legal - Performance - Movimentos sociais - Feminismos latinoamericanos

\footnotetext{
${ }^{1}$ Investigadora de CONICET. Dra. en Estudios Sociales de América latina. Mg. en Sociología. Lic. en Comunicación Social. Directora de El Telar. Comunidad de Pensamiento Feminista Latinoamericano. e-mail: paola.bonavitta@gmail.com
}

Rev. Eletrônica Mestr. Educ. Ambient. Rio Grande, Dossiê temático "Imagens: resistências e criações cotidianas", p. 253-267, jun. 2020. E-ISSN 1517-1256 


\title{
Performance of a movement: the marches for the legalization of abortion in
}

\section{Argentina}

\begin{abstract}
In this article it is proposed to investigate the performance construction of the feminist movement in favor of the legalization of abortion in Argentina. The body and performance language of those who star in the marches in favor of the legal interruption of pregnancy from February 2018 to July 2019 will be analyzed. This temporary cut is due to the fact that it was the most active peak of participation in the marches after the presentation of the bill to the National Congress. The intention is to understand the performance of these mobilizations and the meanings that are created and recreated there from the contributions of discourse analysis and from popular communication, as well as Latin American and decolonial feminism.
\end{abstract}

Keywords: Legal abortion- Performance- Social movements- Latin American feminisms

\section{Introducción}

La Campaña Nacional por el Derecho al Aborto Legal Seguro y Gratuito ${ }^{2}$ (Conocida como La Campaña) creada en Argentina sostiene como lema: Educación sexual para decidir, anticonceptivos para no abortar, aborto legal para no morir. Desde la Campaña sostienen que "despenalizar y legalizar el aborto es admitir que no hay una única manera válida de enfrentar el dilema ético que supone un embarazo no deseado; reconocer la dignidad, la plena autoridad, la capacidad y el derecho de las mujeres para resolver estos dilemas y dirigir sus vidas; y aceptar que el derecho a decidir sobre el propio cuerpo es un derecho personalísimo ya que éste es el primer territorio de ciudadanía de todo ser humano".

La ampliación de la despenalización del aborto y la práctica de la Interrupción Voluntaria del Embarazo (IVE) atraviesan derechos personalísimos de mujeres de todas las clases sociales, pero afectan las vidas de las más pobres. Asimismo, "las disputas por los sentidos en relación al aborto -y por lo tanto, por su regulación- se dan en el espacio político, tanto entre quienes sostienen posiciones conservadoras, como entre quienes defienden los derechos de las mujeres" (JOHNSON, 2018, p. 3).

En este contexto, el 6 de marzo de 2018, en Argentina se presentó nuevamente el proyecto para que se apruebe el aborto legal, seguro y gratuito en el Congreso de la Nación Argentina. Hubo marchas multitudinarias en las principales ciudades del país y lo mismo

\footnotetext{
${ }^{2}$ La Campaña es una amplia y diversa alianza federal, que articula y recupera parte de la historia de las luchas desarrolladas en nuestro país en pos del derecho al aborto legal, seguro y gratuito. Tiene sus simientes en el XVIII Encuentro Nacional de Mujeres realizado en Rosario en el año 2003 y en el XIX ENM desarrollado en Mendoza en el 2004. Impulsada desde grupos feministas y del movimiento de mujeres, como así también desde mujeres pertenecientes a movimientos políticos y sociales, cuenta en la actualidad con la adhesión de 305 grupos, organizaciones y personalidades vinculadas a organismos de derechos humanos, de ámbitos académicos y científicos, trabajadoras/es de salud, sindicatos y diversos movimientos sociales y culturales, entre ellos redes campesinas y de educación, organizaciones de desocupadas/os, de fábricas recuperadas, grupos estudiantiles, comunicadoras y comunicadores sociales, etcétera.
}

Rev. Eletrônica Mestr. Educ. Ambient. Rio Grande, Dossiê temático "Imagens: resistências e criações cotidianas", p. 253-267, jun. 2020. E-ISSN 1517-1256 
sucedió en la movilización del 8 de marzo de 2018 y de 2019, del día internacional de la mujer trabajadora. Además, desde 2015 con la consigna \#Niunamenos, el feminismo se ha constituido en un movimiento político masivo con increíble fuerza en las calles, las miradas sobre las expresiones feministas no están centradas en la necesidad de legalizar el aborto o en las políticas públicas sobre educación sexual integral, sino en los cuerpos de las mujeres y las violaciones que estos cuerpos hacen de los mandatos patriarcales. Cuerpos desnudos y desafiantes, insurrectos, rebeldes. Cuerpos que no se comportan como manda el sistema patriarcal y que viola las normas de la "buena mujer". "Las mujeres desnudas no nos representan", decían en foros y redes muchas otras mujeres que rechazan al feminismo. El lenguaje performático del feminismo es lo que le molesta a la sociedad mucho más que sus consignas e, incluso, la legalización del aborto. No confían en mujeres que andan desnudas en la calle, que escriben paredes, que no quieren ser madres, que les gustan otras mujeres, que gritan y marchan, que no tienen miedos...

En tanto, en las movilizaciones sociales feministas, la consigna excede la protesta, la queja y muchas veces las marchas acaban siendo una fiesta, un espacio de encuentro, de explosión, donde los cuerpos gozosos se mueven al ritmo de cantos, de aplausos, del estarcon-otras.

Es por ello que en este trabajo focalizamos en las movilizaciones feministas en torno al aborto desde marzo de 2018 hasta junio de 2019, en las que las marchas feministas comenzaron a centrarse en la consigna aborto legal. Tenemos en cuenta lo performático de estos encuentros, su estética y su reivindicación como un espacio de lucha por los derechos de las mujeres y diversidades pero también de alegría por encontrarse y reconocerse feministas.

\section{Justificación: El lenguaje de los cuerpos y la performatividad}

Beatriz Preciado (2004) sostiene que lo que podemos definir como performance feminista tiene sus raíces en el teatro de guerrilla y en las revueltas universitarias y callejeras de los movimientos feministas norteamericanos de los años 60 y 70 . Las políticas performativas feministas de finales de los 60 , a diferencia de la imagen clásica del feminismo americano, se caracterizan por ser radicalmente políticas “incorrectas", por hacer una utilización extrema de los recursos identitarios del margen (Preciado, 2004, p.7). Según María Fernanda Pinta (2005) la performance implica un hacer codificado, socialmente prefigurado y significativo en su capacidad para definir identidades e 
interacciones humanas posibles. Performance es también un hacer cuya significación se construye en el propio proceso, que puede poner en crisis aquello que representa, que puede desarticular las posiciones ontológicas con que se anclan cuerpos, deseos y sexualidades (PINTA, 2005, p.12).

¿Por qué hablar de performance cuándo analizamos las marchas feministas? Porque las marchas feministas no sólo utilizan tambores y cánticos populares como en el resto de las movilizaciones populares, sino que emplea una estética determinada, cuerpos pintados y trabajados para la ocasión, espectáculos callejeros, danzas, rituales, improvisaciones teatrales y obras preparadas. En el caso de Argentina y las marchas a favor de la legalización del aborto, éstas se tiñen de color verde (que es el color que adoptó como emblema la Campaña Nacional por el derecho al Aborto legal, seguro y gratuito) y también de violeta (el color que representa históricamente al movimiento feminista). Las vestimentas, los brillos, los carteles, los cuerpos portan estos colores y ello ha desembocado en que se denomine a este movimiento feminista de lucha por el aborto legal como "Marea Verde"3. La performance permite la experiencia del momento, del instante, es allí donde la inmediatez adquiere significado. Y esos cuerpos "acuerpados" recrean y sostienen múltiples significados que, por más que su expresión sea efímera, se retiene en el imaginario feminista nacional y se replica a lo largo del país.

Entendemos junto con Schechner que la base teórica subyacente (sobre la idea de performance) son "las actividades humanas -sucesos, conductas- que tienen la cualidad de 'conducta restaurada', o 'conducta practicada dos veces'; actividades que no se realizan por primera vez sino por segunda vez y ad infinitum" (SCHECHNER, 2000, p. 2). Ese proceso de repetición -ausencia de 'originalidad' o 'espontaneidad'- es la marca distintiva de la performance, sea en las artes, en el juego, la vida cotidiana, la ceremonia, el ritual, el juego (SCHECHNER, 2000). Para este autor, la performance tiene carácter representacional, de puesta en escena. Moviliza expresiones corporales y representaciones que toman carácter político por las particularidades de sus estrategias. Como marca Stiles (1996): "La performance captura las contradicciones políticas y los conflictos de su propio período histórico de forma vívida, amenazando el status quo, la supresión de discordia y el control y administración de los cuerpos". Y las performances que actúan en las marchas

\footnotetext{
${ }^{3}$ Se denomina Marea Verde al movimiento feminista a favor de la legalización del Aborto debido a que en sus marchas se utiliza su símbolo-emblema: el pañuelo verde de La Campaña nacional por el derecho al aborto legal, seguro y gratuito. Recordemos que, en Argentina, durante la última dictadura militar (1976-1983), los pañuelos blancos fueron el emblema de las Madres de Plaza de Mayo, que comenzaron a usar ene. sus cabezas pañuelos fabricados con tela para pañales, simbolizando los hijos desaparecidos por los genocidas. Inspiradas en esta historia, el movimiento feminista creó el Pañuelo Verde. En las marchas, desde tomas en altura, se ve como una gran Ola o Marea de gente con el color verd.
} 
feministas desafían justamente todo los mandatos patriarcales sobre las mujeres. Según el sistema patriarcal, las mujeres deben/debemos ser heterosexuales, maternales, sensibles, tranquilas, pasivas, apolíticas, replegadas al espacio privado, adaptables. Y la Marea Verde justamente es todo lo opuesto: insurrecta, rebelde, desafiante, política, diversa, autónoma.

En el lenguaje performático, las y los artistas no representan personajes al modo del teatro tradicional, no obstante, su conducta presenta una serie acciones programadas socialmente. "Habría, por lo tanto, determinadas reglas de comportamiento esperadas y reproducidas tanto si se las cumple como si se las rompe (el hecho de romperlas implica el conocimiento de su existencia)" (PINTA, 2000, p. 3). En lo performático de las marchas justamente se encuentra el hecho de romper algunas reglas de esta sociedad que castiga la autonomía de los cuerpos, las decisiones de las mujeres y cuerpos gestantes. Además, lejos de generarse como obra individual, las performances feministas aborteras son colectivas y cooperativas, en las que prima la hermandad y se desafía la idea de "genio individual" propia de Occidente y de la Modernidad. Las aborteras desafían además los patrones estéticos hegemónicos, los mandatos acerca de qué cuerpos sí pueden desnudarse y cuáles no. Son cuerpos diversos y eso se convierte, adrede, en una posición política que apuesta a desenmascarar las normas de todo tipo.

\section{Aproximaciones metodológicas: ¿Cómo ver? Lecturas sobre la imagen}

Desde la comunicación, como campo disciplinar, todo comunica. Es decir que nada que se presente en este universo que habitamos simplemente es, sino que también dice, expresa, comunica. Comunicar es poner en común. La comunicación es una común-unión entre las personas que participan de un encuentro determinado.

Las imágenes, por ende, también transmiten sentidos, enunciaciones y significados. No hay imagen que no transmita algo, que no comunique. Por tanto, en este trabajo apuntaremos a analizar algunas de las imágenes que se han tomado como representativas de las marchas a favor de la legalización del aborto en Córdoba, Argentina. Cabe aclarar que Córdoba es la segunda ciudad más poblada de Argentina, no obstante sigue siendo parte de la Argentina profunda, del interior de un territorio federal que concentra sus riquezas, accesos y poder en su capital. Córdoba es una ciudad que ha apostado al neoliberalismo, es Córdoba "de las campanas" 4 , es "la Docta" 5 , ultraconservadora y

\footnotetext{
${ }^{4}$ El poeta Arturo Capdevila definió alguna vez a Córdoba como la ciudad de las campanas por la gran cantidad de iglesias que forman parte de la ciudad.
}

Rev. Eletrônica Mestr. Educ. Ambient. Rio Grande, Dossiê temático "Imagens: resistências e criações cotidianas", p. 253-267, jun. 2020. E-ISSN 1517-1256 
católica que, sin embargo y a pesar de ello, ha encabezado insurrecciones populares claves en la historia del país. El Cordobazo ${ }^{6}$ o la Reforma Universitaria de $1918^{7}$ son ejemplos de que en Córdoba los levantamientos populares han sido fuertes y revolucionarios. No obstante, a pesar de este conservadurismo ${ }^{8}$ propio de la ciudad y de la provincia de Córdoba, quedan espacios y márgenes para que exploten las revoluciones y estallen las esperanzas. El movimiento feminista es, actualmente, el espacio más revolucionario que se presenta en un escenario que exige y reivindica la legalización del aborto.

En este trabajo analizamos las imágenes de las marchas y movilizaciones que exigen la legalización del aborto y la educación sexual integral. La evolución de la imagen ha permitido construir la memoria visual del hombre, en todas y cada una de sus manifestaciones. La imagen, como lenguaje propio y autónomo, nos permite analizar los sentidos que se manifiestan en un espacio y tiempo determinados que quedan congelados para recuperarse una y otra vez. Según Pantoja Chávez (2007, p. 186):

\begin{abstract}
“(...) la fotografía no es sólo un soporte para la imagen, es además un soporte de y para la memoria, ya que su fuerza y atractivo reside en su capacidad técnica de suspender el tiempo y centrar el espacio en un instante. Nos permite, por tanto, recordar constantemente todos aquellos hechos que nos hemos esforzado en memorizar mediante la lectura. Visualizar los recuerdos en la fotografía es una versión más de hacer memoria, de no olvidar un pasado que se ha preservado en esas imágenes que una y otra vez la fotografía nos devuelve ante nuestra atenta mirada".
\end{abstract}

La imagen como dato ayuda a contextualizar lo observado y posibilita profundizar sobre aspectos menos visibles en otros modos de registro de lo observado. Desde la semiología, Roland Barthes (1980), argumenta que la imagen fotográfica es la

\footnotetext{
${ }^{5}$ El apodo La Docta que tiene Córdoba se debe a que su Universidad, fundada en 1613 por la Compañía de Jesús, fue durante más de dos siglos la única del país y una de las primeras de América. Se la llamaba coloquialmente Casa de Trejo, por el obispo, y con ella empieza la educación superior en Argentina.

${ }^{6}$ El Cordobazo o primer Cordobazo, fue una insurrección popular sucedida en la ciudad argentina de Córdoba, el 29 y 30 de mayo de 1969. Fue liderada por Elpidio Torres y Atilio López, secretarios generales respectivamente de los sindicatos SMATA (mecánicos) y Unión Tranviarios Automotor, pertenecientes a la Confederación General del Trabajo (CGT), y Agustín Tosco del sindicato de Luz y Fuerza de la CGT de los Argentinos. Formó parte de una serie de puebladas en Argentina entre 1969 y 1972 - todas ellas nombradas con palabras terminadas con el sufijo "azo"-, contra la dictadura gobernante autodenominada "Revolución Argentina". Las puebladas de 1969 y comienzos de 1970 debilitaron al gobierno militar y fueron uno de los factores que llevaron al reemplazo del dictador Juan Carlos Onganía en junio de 1970, abriendo paso a una salida electoral que terminó concretándose con las elecciones de 1973.

${ }^{7}$ La Reforma Universitaria de 1918, Reforma Universitaria de Córdoba, Reforma Universitaria de Argentina, Grito de Córdoba, o simplemente Reforma Universitaria, fue un movimiento de proyección juvenil para democratizar la universidad y otorgarle un carácter científico, que se inició con una rebelión estudiantil en la Universidad Nacional de Córdoba de Argentina que se extendió entre marzo y octubre de 1918, durante el cual se produjeron violentos enfrentamientos entre reformistas y católicos. Su fecha simbólica es el 15 de junio de 1918, momento en el cual los estudiantes irrumpieron en la Universidad para impedir que se consumara la elección del rector que sostendría la situación tal como estaba hasta entonces y declararon una segunda huelga general.

${ }^{8}$ Cabe aclarar que Córdoba es la provincia con el índice más alto de electorado macrista y, por ende, conservador y neoliberal. En Córdoba ganó las elecciones de 2015 Mauricio Macri, candidato del PRO, con más del 70\% de los votos y en las recientes elecciones de 2019 Macri obtuvo más del 60\% de los votos a su favor.
}

Rev. Eletrônica Mestr. Educ. Ambient. Rio Grande, Dossiê temático "Imagens: resistências e criações cotidianas", p. 253-267, jun. 2020. E-ISSN 1517-1256 
reproducción analógica de la realidad,"lo que caracteriza a las sociedades llamadas avanzadas es que tales sociedades consumen en la actualidad imágenes y ya no, como las de antaño, creencias" (BARTHES, 1980, p. 199). Este consumo masivo de la imagen inherente a las sociedades modernas, se debe a las funciones que tiene la fotografía, a saber: informar, representar, sorprender y hacer significar. Esto supone, que la fotografía como productora de códigos también es lenguaje visual, "el estilo es lo que hace que la fotografía sea un lenguaje. (...) La fotografía lleva su referente consigo: no hay foto sin algo o alguien. La esencia de la fotografía es la obstinación del referente de estar siempre allí” (BARTHES, 1980, p. 152). Con la fotografía no se puede negar que la cosa o sujeto haya estado allí, esto significa que existe una doble posición: de realidad y de pasado. Entonces, la imagen se vuelve testimonio congelando así el presente y el paso del tiempo (Bonetto, 2016, p. 34).

Según Bonetto (2016, p. 34), la fotografía aparece como un elemento visible de un trasfondo que se hace visible en el material fotográfico, pero que tiene elementos que, en la realidad, son invisibles y nos invitan a interpretar e interrogarnos acerca del sentido de la imagen. Es por ello que la fotografía se ubica como una herramienta para la reunión de datos en la investigación social. En este trabajo analizamos las imágenes provenientes de la marcha del 8 de marzo de 2018 y 2019 en Córdoba, Argentina, así como la marcha del 3 de junio de 2018 y 2019 (marcha Ni Una Menos) donde la consigna central fue Aborto legal, Seguro y Gratuito. Tomamos imágenes del archivo público de Medionegro y de Ni Una Menos Córdoba, quienes cubrieron lo que sucedió en esas marchas multitudinarias.

\section{Discusiones: Cuerpos danzantes y en rebeldía}

[...] y ahora que estamos juntas, y ahora que sí nos ven.

Luchar por la autonomía de los cuerpos es clave en el marco de una lucha feminista. Resistir a las opresiones patriarcales y a los controles corporales embandera a un movimiento que posibilita el acceso a libertades múltiples. Los 8 de marzo, las mujeres, lesbianas, trans, tortas, bisexuales y no binaries marchamos en el marco del Día internacional de la Mujer Trabajadora, y los 3 de junio bajo la consigna \#Niunamenos. No obstante, desde hace dos años, en Argentina se moviliza fuerte la lucha por el Aborto Legal, Seguro y Gratuito como derecho a adquirir en una sociedad que controla, reprime y castiga 
a los cuerpos de las mujeres y disidencias. Esas marchas y movilizaciones se convierten en una fiesta en la que no están autorizados a estar los varones cis.

Las imágenes revelan en qué se convierten esos eventos y lo festivos que resultan. El feminismo es consciente de que el patriarcado, el capitalismo y el colonialismo nos ha saqueado, no obstante reivindica la alegría como bandera. Y es la alegría, justamente, lo que se manifiesta en esos encuentros multitudinarios. Desde Córdoba se impulsa una fuerte resistencia a las intenciones del Estado cisheteropatriarcal que censura a las mujeres y sus expresiones, así como violenta permanentemente sus cuerpos al obligar a parir a quien no lo desea, incluso a niñas, bajo argumentos morales y religiosos, que dejan al margen el debate acerca la educación sexual integral y el acceso a la salud pública de manera digna.

En ese marco, las movilizaciones se traducen en una fiesta. Se reclama un derecho personalísimo, pero se lo hace desde la unión, la comunidad, la expresión colectiva. Y es por ello que se transforma en una sumatoria de performances o en una gran performance colectiva.

Las fotografías nos muestran cómo se vive como una fiesta feminista: cuerpos danzantes, sonrientes, pintados con colores, brillos, leyendas escritas en los cuerpos de las mujeres y disidencias. Sin importar la edad, la piel ni el partido político, las movilizaciones marcan cuerpos insurrectos que desafían la represión del estado patriarcal. Contenidas en la "marea verde", las mujeres y disidencias se sienten seguras, en un clima marcado por la sororidad. La imagen refleja y congela las expresiones que engalanan la movilización y que la convierten en una performance que vehiculiza sentidos y significados propios de la lucha feminista.
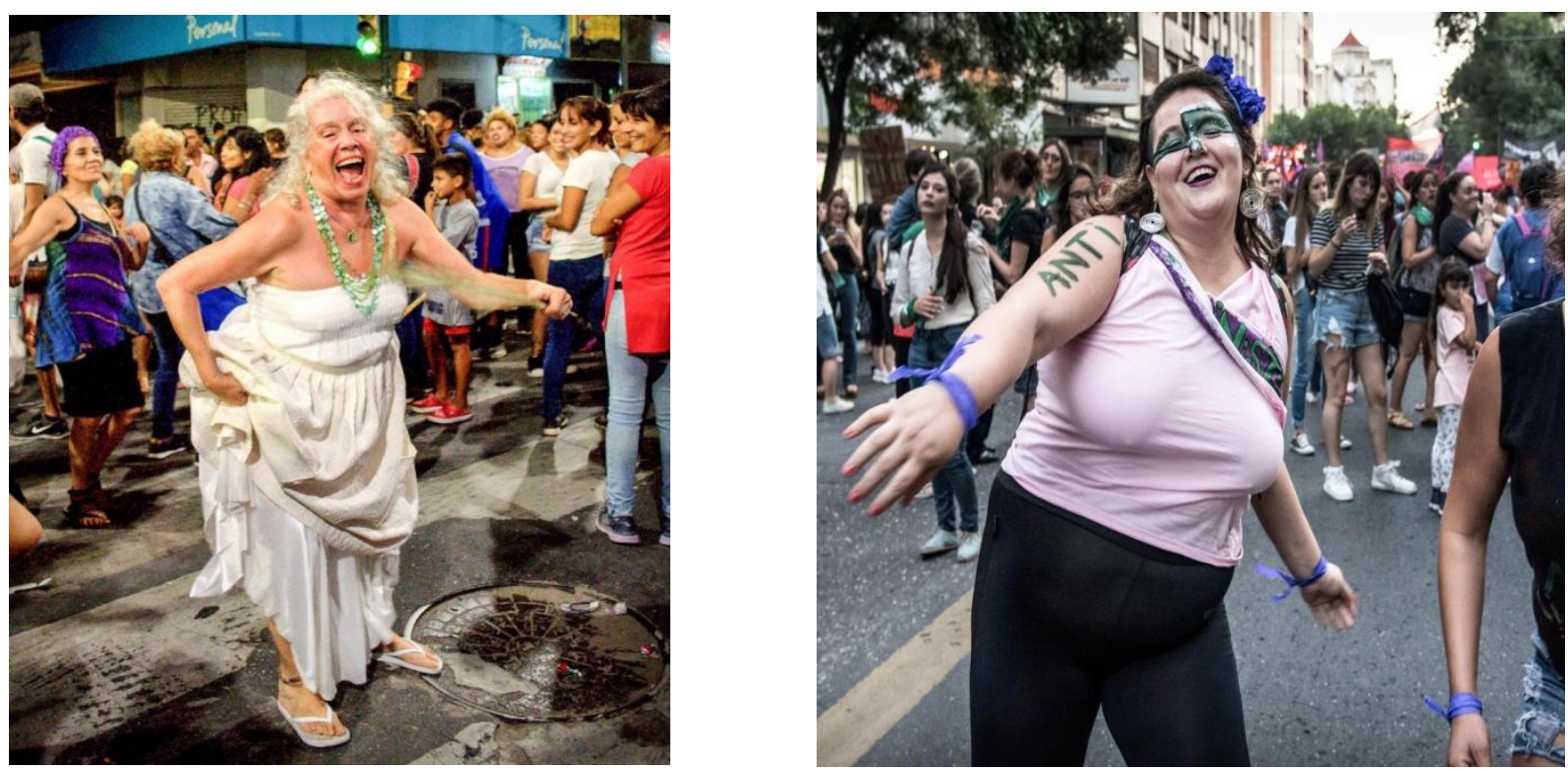

Archivo Medionegro: Las feministas haciendo historia. Marzo 2018.

Rev. Eletrônica Mestr. Educ. Ambient. Rio Grande, Dossiê temático "Imagens: resistências e criações cotidianas", p. 253-267, jun. 2020. E-ISSN 1517-1256 
¿Qué se danza? El sentirse en tribu, en manada. El estar cerca del objetivo de la legalización del Aborto en el país. Se danza el encuentro con las otras de manera multitudinario. Se danza para honrar la vida de las que ya no están, de las que murieron víctimas de feminicidio y para honrar la memoria de quienes han iniciado y sostenido las luchas feministas a lo largo de los años. Se danza por los logros obtenidos por nosotras mismas y porque están/estamos juntas. A lo largo de la marcha se canta con fuerza: "Ahora que estamos juntas, ahora que sí nos ven: abajo el patriarcado, se va a caer, se va a caer! Arriba el feminismo que va a vencer, que va a vencer!". Y esa frase sintetiza el sentir colectivo. Históricamente las mujeres han sido silenciadas e invisibilizadas, se les ha negado valor a su palabra y se les ha impedido el ejercicio de la autonomía y la toma de decisiones. El estado patriarcal, ante tan multitudinaria manifestación feminista, no puede continuar invisibilizando al feminismo como sujeto colectivo activo y político y, por ende, ya no puede acallar sus demandas.
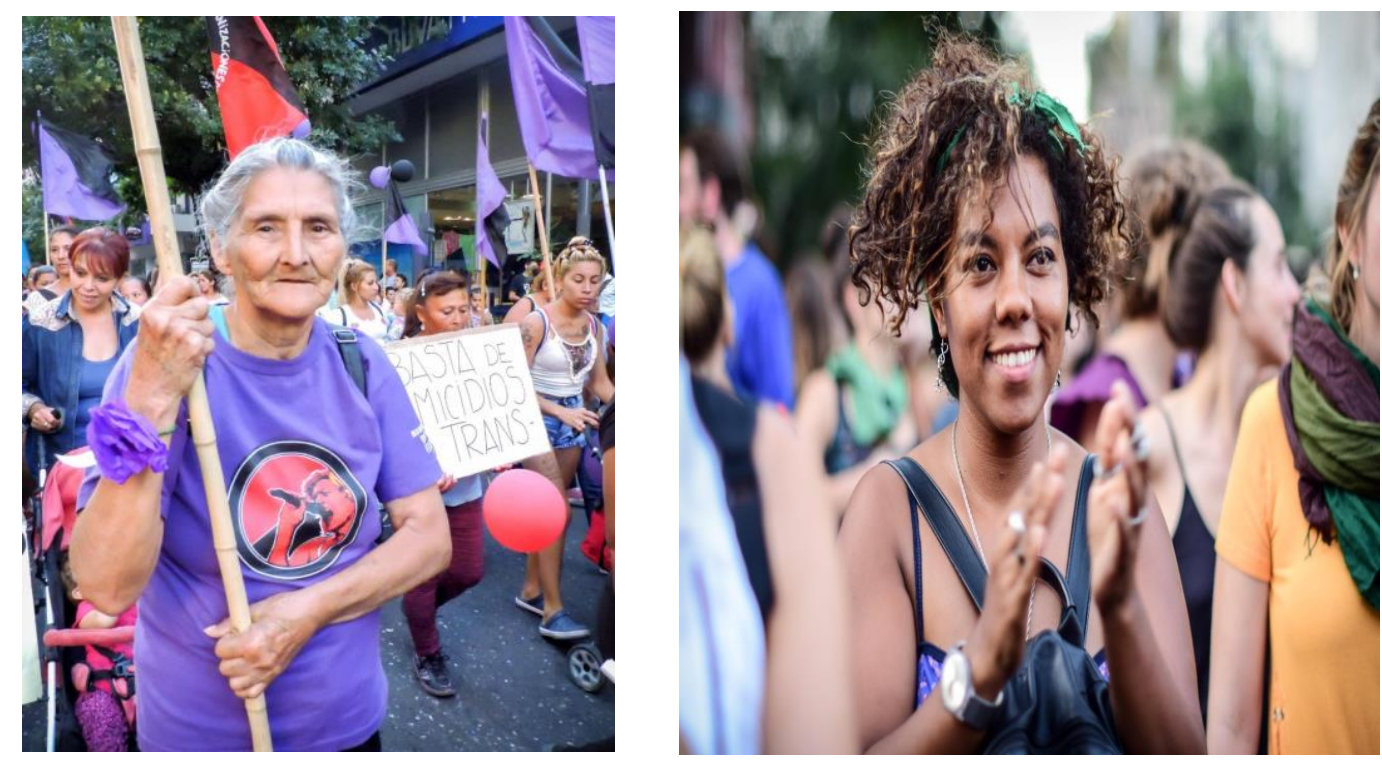

Archivo Medionegro: Las feministas haciendo historia. Marzo 2018.

En el marco de las movilizaciones feministas, se cuestiona fuertemente la existencia de un sujeto hegemónico. Ello desafía las concepciones de mundo que propone Occidente. Las lecturas interseccionales de género, clase, raza y edad que permite la perspectiva latinoamericana, nos facilita la inclusión de sujetos múltiples en los espacios de la ciudad, tomando y desafiando al estado patriarcal. En lo performático del encuentro colectivo, se refleja la variedad de mujeres que nos habitan y se desarma la idea de "la mujer" como sujeto universal. 
La performance tiene mucho de espontáneo. Y ese es uno de los rasgos que se presentan con mayor énfasis en estas movilizaciones. Van surgiendo los cuerpos pintados y las danzas tribales, en un encuentro que se manifiesta intenso y hasta desgarrador por momentos. Allí donde el Estado no está actuando, las feministas se "acuerpan". Caras pintadas, cuerpos escritos, pañuelos por doquier, gritos de tribu, corridas, tambores, rabia por las muertas, furia por la naturalización de esas muertes. En un acto político permanente, las marchas feministas no pierden la consigna clave que las genera y apuestan al escándalo para visibilizarse ante un Estado que opone resistencias y que no facilita el acceso a la salud pública de las mujeres.

Pocas veces, desde el retorno a la democracia en Argentina en 1983, se ha luchado tanto por conseguir un derecho. En este marco, el movimiento de mujeres ha sostenido un activismo permanente que ha ido mutando sus formas, el número de personas que forman parte de la lucha y las performances políticas que se implementan. El feminismo sostiene la defensa de que los derechos de toda persona en relación a su sexualidad pueden ser reproductivos o no reproductivos, y el Estado debe garantizar ambos tipos de derechos con políticas adecuadas.
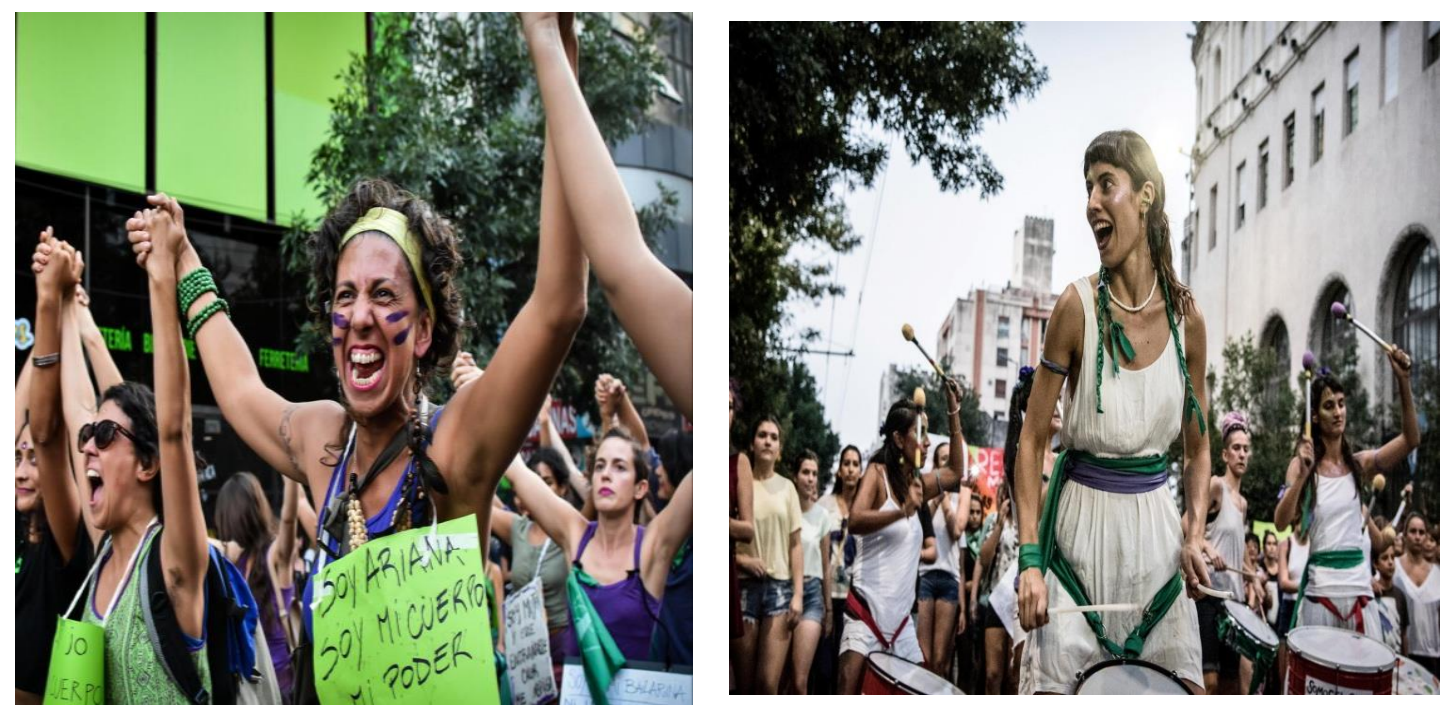

Archivo Medionegro: Las feministas haciendo historia. Marzo 2018.

Rev. Eletrônica Mestr. Educ. Ambient. Rio Grande, Dossiê temático "Imagens: resistências e criações cotidianas", p. 253-267, jun. 2020. E-ISSN 1517-1256 


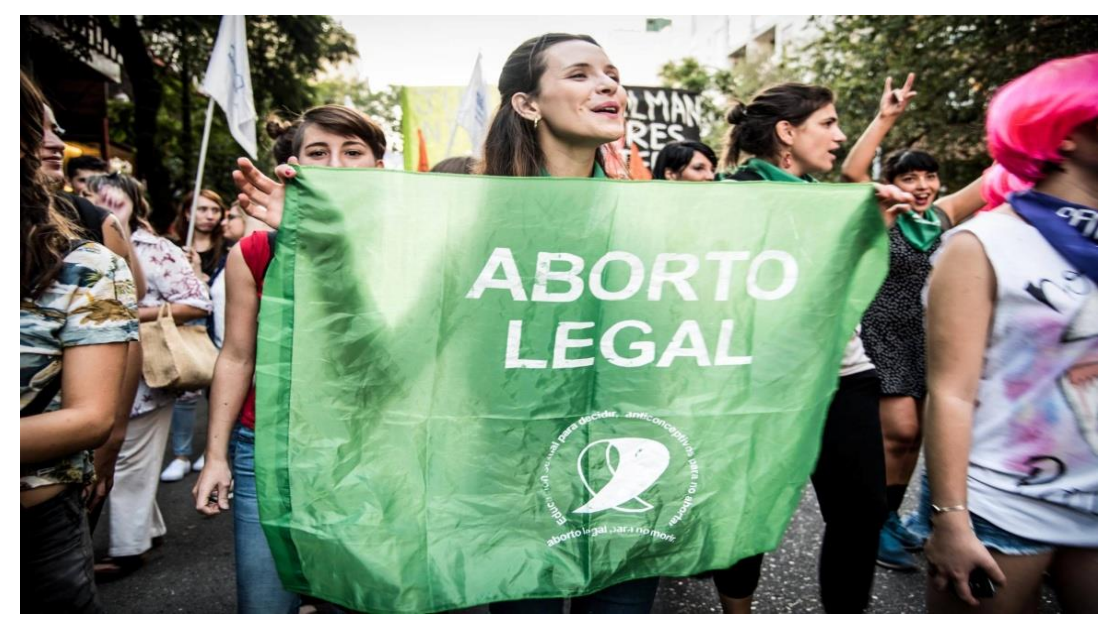

Archivo Medionegro: Las feministas haciendo historia. Marzo 2018.

En este contexto social, pasamos de la resistencia a la re-existencia. Es decir, que el movimiento feminista ha pasado muchos años resistiendo a un Estado y una sociedad patriarcal y ahora es momento de re-existir. En esa re-existencia, las masivas marchas así como el encuentro transgeneracional entre feministas diversas nos está permitiendo la posibilidad de pensar nuevas acciones y estrategias para ser y hacer de maneras novedosas, complejas y activas.

Porsupuesto que esta presencia permanente de las feministas en los distintos ámbitos de la sociedad -desde la participación callejera hasta la injerencia institucionalgenera rechazos y temores en los sectores conservadores de la sociedad. Esto se refleja en el incremento de las violencias machistas. En Argentina muere una mujer cada 30 horas víctima de un femicidio. La digna rabia y el dolor que contemplan las violencias, los abusos, las violaciones y femicidios no acallan la alegría del encuentro. Desde los feminismos argentinos se propone sostener la alegría, que al estar en sororidad con las otras mujeres, ya ninguna otra estará sola. Toda la movilización contempla esta idea.

En nuestros encuentros, cuando sentimos que el poder feminista y popular va multiplicándose como revoluciones potentes a partir de dos claves fundamentales: la unidad de las mujeres, lesbianas, travestis, trans, bisexuales y otras tantas identidades femeninas que están reconociéndose como tales, y la visibilidad de nuestros cuerpos y de nuestros actos que ahora "sí nos ven" (KOROL, 2019, p. 1).

La marea verde se expresa en las calles con la rebeldía de quien enfrenta al sistema patriarcal pero también con la pasión de los logros obtenidos. "Pedagogía y comunicación feminista, son algunas de las estrategias con las que vamos creando "comunidad", un modo de actuar que aprendimos, en el que "si tocan a una respondemos todas". Va naciendo 
también, a los tumbos, una ética feminista del acompañamiento" (KOROL, 2019), que se enmarca en la alegría de nuestras luchas. Esos cuerpos son cuestionados: son cuerpos pintados, desnudos, rebeldes, con sonrisas, cuerpos que danzan... El patriarcado quiere a las mujeres quietas, calladas, en sus hogares.
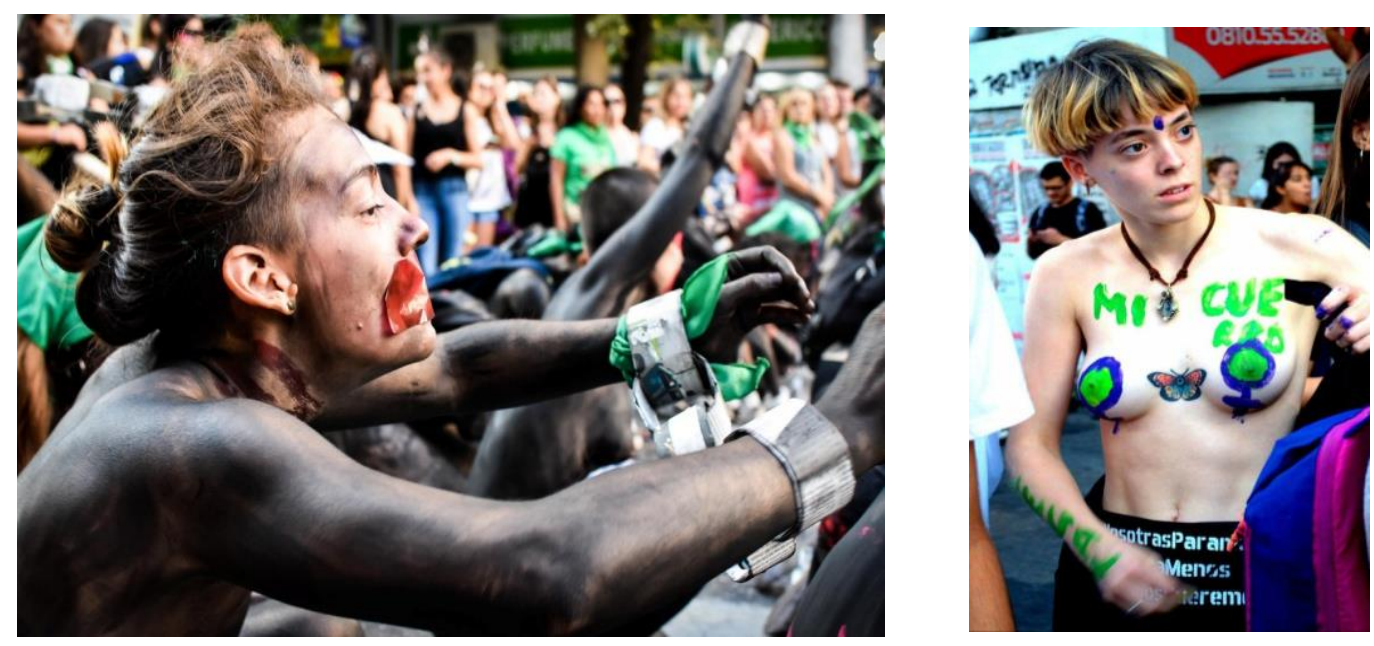

Archivo Medionegro: Las feministas haciendo historia. Marzo 2019.

Las mujeres recuperan lo tribal: se danza colectivamente, en círculo, mirándose a la cara, contagiándose las sonrisas. Se cierran las expresiones artísticas y musicales así como las demandas políticas concretas con un grito de guerra indio -tribal y colectivo- que marca la noción de comunidad. Los cuerpos pintados también remiten a la idea de tribu en la que el cuerpo mismo es arte, es expresión, es marca. Los cuerpos desnudos también desafían a la norma: el heterocispatriarcado moderno-occidental habla de "un" único cuerpo de mujer. Aquí, entre las desnudas expresiones corporales, la norma se cae por su propio peso, por la clara manifestación de la heterogeneidad. Las marchas feministas nos muestran a mujeres libres, rebeldes, incumplidoras.

Las mujeres que marchan desnudas exigiendo el derecho al aborto legal (que no es otra cosa que un reclamo de salud pública): no son los cuerpos normados, no son dóciles, no son morales. Son cuerpos disidentes que escapan a las normas, y desafían los sexismos, que ocupan los espacios públicos sin permiso y desafían las lógicas de las prácticas posibles. Son cuerpos políticos. Son cuerpos que cuestionan el vínculo entre ser mujer, ser madre y ser cuidadora (BONAVITTA, 2018, p. 7).

Para María Galindo (2015, p. 12), estas manifestaciones que se viven desde el feminismo se transforman en rebeliones mudas: "que están cambiando de manera silenciosa el panorama [...] en nuestras sociedades y que son rebeliones que representan 
rupturas a las que la sociedad reacciona con una especie de neurosis porque no las quiere ni ver, ni asumir como tales". Para la autora, estas rupturas que protagonizan las mujeres a escala continental tienen que ver con:

la ruptura de toda división sexual del trabajo, la emancipación económica de facto, la práctica ilegal del aborto de forma masiva, el rechazo de las mujeres a someterse a la violencia machista, la ruptura de la división sexual del conocimiento, entre otras muchas desobediencias cotidianas (GALINDO, 2015, p. 13).

Entre esas rebeliones, se apunta a que "ninguna mujer sienta que tiene que ser madre por obligación" (GALINDO, 2015, p. 13). Y es allí donde el Estado interfiere, se molesta, se rabia. Y enfoca en los cuerpos insurrectos, marcados por las rebeldías: las tetas al aire, los cabellos teñidos de colores vivos (verdes, fucsias, violetas), las colas desnudas. Y el patriarcado se escandaliza pues esas mujeres salieron de sus casas, deciden sobre sus cuerpos y gozan. Gozan allí cuando nadie les dio el permiso para hacerlo (BONAVITTA, 2018).

\section{A modo de cierre: consideraciones finales}

Porque tu lo sabes bien, compañera y hermana, estamos en una guerra. Ellos por matarnos. Nosotras por vivir, pero vivir sin miedo, vivir libres pues. Mujeres Zapatistas, 2019.

Para el movimiento feminista argentino, 2020 es un año clave. Frente a un cambio de gobierno, se espera que se legalice finalmente el aborto en todo el territorio nacional. Por tanto, se sostienen las marchas y movilizaciones, así como la presencia de la Marea Verde en todo el país. Performáticamente, se mantiene una estética festiva en cada una de las apariciones del movimiento. Envueltas en verde y violeta, el movimiento feminista activa sus participaciones marcadas por los brillos, los colores, los fuegos verdosos en el aire, los tambores y las danzas que desafían el sentir rabioso de las muertes que podrían haberse evitado.

En un país donde las niñas son obligadas a parir, donde 109 mil adolescentes y 3 mil niñas menores de 15 años, tienen un hijo cada año, lo cual representa el $15 \%$ de los nacimientos ocurridos en el país, el aborto legal se convierte en un derecho que el Estado debe brindar y reconocer. El acceso al aborto legal es parte de la posibilidad que deben tener mujeres y niñas de acceder y transitar una vida digna. 
En Argentina, el movimiento de mujeres, a través de las Socorristas en red, hace años ha tomado en sus manos acompañar a las mujeres a abortar de modo seguro de manera de preservar sus vidas. El que está ausente es el Estado, y sobre eso se debe legislar. El desencuentro entre el Estado y las mujeres es lo que las feministas están subsanando. Tal como sostiene Diana Maffía (2018, p. 1.): “La criminalización del aborto no ha resultado eficaz para bajar el número, pero sí ha resultado eficaz para amenazar la vida, la salud y la autonomía de todas, las que parimos y las que abortamos". El aborto constituye una demanda permanente del movimiento de mujeres desde el retorno de la democracia. En todos los Encuentros Nacionales de Mujeres se ha expresado con fuerza y sostenidamente.

Hoy, en un presente marcado por un contexto neoliberal, ultracapitalista y donde las conquistas por los derechos humanos de la región están retrocediendo, la lucha por el aborto aparece como la esperanza central del movimiento feminista. Esa esperanza se manifiesta sin pausa en cada marcha y sus construcciones performáticas: la danza, la alegría, los cantos y las expresiones de algarabía se manifiestan permanentemente. Se pasa de la resistencia del feminismo a la re-existencia de nuevas formas de hacer feminismos y políticas públicas con perspectiva feminista, no binaria y diversa.

Tal como señala Claudia Korol (2018, p.1): "Nuestros corazones rebeldes se encuentran en estado de alerta. La marea verde invade las ciudades, y va arrastrando los prejuicios sembrados históricamente por quienes pretenden controlar nuestros cuerpos de mujeres, o si no lo logran, expulsarnos del Paraíso". Asimismo, Korol comenta cómo este movimiento pro-aborto legal ha permitido sincerar los vínculos transgeneracionales pues ha permitido que las mujeres hablen de los abortos que realizaron, que cuenten cómo fue hacerlo en la clandestinidad, se rompen tabúes y se rompe la hipocresía social.

La marea sigue tiñendo ahora las calles y los corazones de las personas con capacidad gestante. El miedo ahora lo respiran ellos. Alrededor de las brasas de los fogones, arde la rebeldía. El feminismo hoy está guevariando la historia. Ya no habrá revoluciones sin nosotras (KOROL, 2018, p. 2).

Esta lucha se convierte en un hito a nivel regional donde los pañuelos se expanden sin cesar y el tema sale del clóset para instalarse en todos los espacios de la sociedad. Como una puesta en escena artístico-política, las performances feministas articulan la alegría de la re-existencia y el fuego de la digna rabia. 


\section{Referencias}

BARTHES, Roland (1980). La cámara lúcida. Barcelona: Paidós.

BONAVITTA, Paola (2018). Cuerpxs Insurrectxs en lucha por el aborto legal: desafíos al estado patriarcal. Revista Eletrônica Interações Sociais. v. 2, n. 1. Disponible en https://periodicos.furg.br/reis/article/view/8031:. Consultado por última vez el 27/12/19.

BONETTO, María Julia (2016). El uso de la Fotografía en la investigación social. Revista Latinoamericana de Metodología de la Investigación Social. № 11. Año 6. AbrilSeptiembre 2016. Argentina. pp. 71-83.

GALINDO, María (2015). La revolución feminista se llama Despatriarcalización. En Descolonización y despatriarcalización de y desde los feminismos de Abya Yala. Buenos Aires: ACSUR.

KOROL, Claudia (2019) 3 de junio: Y ahora que estamos juntas. Especial Revista Marcha. Disponible en: https://www.marcha.org.ar/3-de-junio-y-ahora-que-estamosjuntas/ Consultado por última vez el 27/12/19.

KOROL, Claudia. (2018) Discurso en el debate parlamentario por la legalización del aborto. Buenos Aires. Disponible en:http://www.sinpermiso.info/textos/argentina-lamarea-verde-conquista-el-derecho-al-aborto-dossier. Consultado por última vez 24/2/20.

MAFFÍA, Diana (2018). Discurso en el debate parlamentario por la legalización del aborto. Buenos Aires. Disponible en:https://www.sinpermiso.info/textos/argentina-lamarea-verde-conquista-el-derecho-al-aborto-dossier. Consultado por última vez 24/2/20.

PANTOJA CHÁVEZ, Antonio (2007). La imagen como escritura. El discurso visual para la historia. Norba. Revista de Historia. Vol. 20, 185-208.

PINTA, María Fernanda (2005) El género en escena : performance y feminismo. Revista Telón de fondo. $\mathrm{N}^{\circ}{ }^{\circ}$ 2. Diciembre. Disponible en: https://www.telondefondo.org/numerosanteriores/numero2/articulo/17/el-genero-en-escena-performance-y-feminismo.html.

Consultado diciembre 2019.

PRECIADO, Beatriz (2004). Género y performance. Revista Zehar, 54, pp. 1-14.

SCHECHNER, Richard (2000). Performance, teoría y prácticas interculturales. Buenos Aires: Libros del Rojas, pp.11-20.

STILES, Kristine (1996) "Performance Art". En Stiles y Selz (ed.), Theories and Documents of Contemporary Art. Los Angeles: California University Press.

Submetido em: 12-03-2020.

Publicado em: 01-07-2020. 